\title{
Perception of the Educational Community on the Influence of Affectivity on Academic Performance
}

\author{
Jaime A. Beltrán Bernal 1,2 \\ ${ }^{1}$ Plant teacher at José Celestino Mutis Educational Institution, San José del Guaviare, Colombia. \\ ${ }^{2}$ PhD. Candidate University Cuauhtémoc Aguascalientes Campus-México.
}

Corresponding Author: Jaime A. Beltrán Bernal. E-mail: jaimebeltran2020@yahoo.com

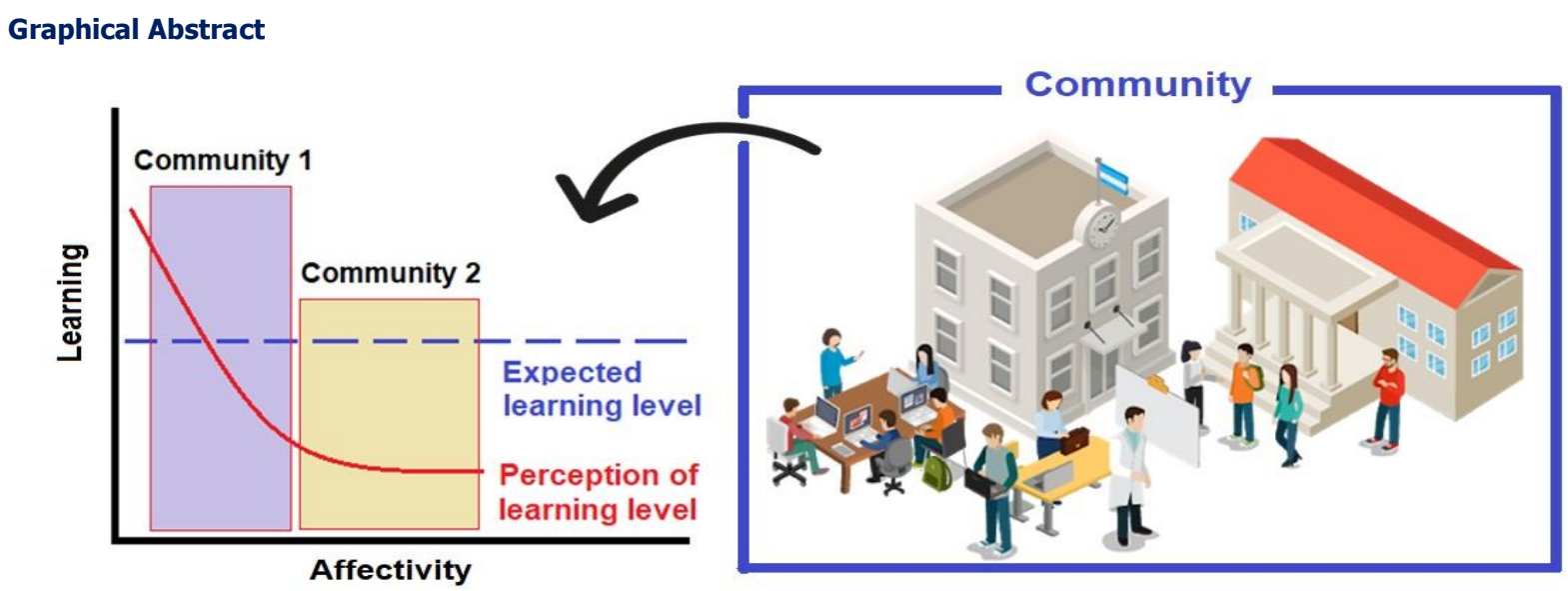

\begin{abstract}
This research, carried out between 2017 and 2018, aims to analyze the perceptions that adolescent students, parents and teachers have about the influence of affectivity on the academic performance of the students of the El Resbalón Educational Institution of San José del Guaviare (Colombia). The problem is based on the low academic performance of the students, the constant reprimands and citation of parents of families for the bad behavior of their adolescent children during the teaching-learning processes. With observation, interviews, life stories, case studies, documents and records, information is collected to make an analysis of the discourse of the studied phenomenon, with the help of Atlas.ti. According to this information, a direct interpretation of the phenomena is made as a whole, so that through the triangulation the respective analysis and validation of the data is carried out. In this way, the results showed that parents consider their adolescent children as people with great maturity and responsibility, assigning them functions that are their parents' responsibility. Therefore, it can be concluded that the academic performance of the adolescent student is negatively affected by the lack of affective relationships with their relatives. In the teaching-learning processes, the implementation of an affective education is also needed so that the adolescent feels more empathy towards the teachers and to impart the classes.
\end{abstract}

Keywords: Affectivity, academic performance, adolescents, parents, teachers.

Cite as: Beltran Bernal Jaime. Perception of the Educational Community on the Influence of Affectivity on Academic Performance. J. Sci. Technol. Appl. 9 (2020) 35-41. 


\section{Introduction}

The human being uses strategies in order to achieve knowledge. In the educational field, he has devised and implemented different educational theories, in order to ensure a high academic performance of the student, such as discovery learning, meaningful learning, cognitivism, constructivism, the theory of multiple intelligences and the theory of social learning, whose precursors have been Piaget, Bruner, Ausubel, Vygotsky, among others. Indeed, academic performance is part of these theoretical processes, and is usually analyzed from an educational perspective, to identify the factors that affect it positively or negatively.

Affectivity in adolescent students is one of those factors, through which an adequate academic performance may or may not be obtained. The construction of the concept of adolescence has been carried out for centuries from numerous studies. Authors such as Palacios, Marchesi and Coll (1999) expressed that from Greek philosophy adolescence was defined as a phase of rebellion, of questions about the outside world and of exploration of the place of the individual in society. Likewise, Rodríguez et al. (1995) considered that the adolescent concept is linked to the generalization of formal education and the way in which the family and society assume it, since it is understood that this is the area that introduces the subject into adult life and work.

Undoubtedly, affectivity must be taken into account in the training processes and put into practice in the classrooms, where students have to be guided and understood from an affective education, and through comprehensive training. In the research by Calupiña and Zambrano (2018), a deficient knowledge of social and affective development is evidenced, and the lack of application of strategies to strengthen it. Therefore, educators also need to develop effective competencies to analyze student behaviors. However, issues such as difficulties in the school climate, class planning, pedagogical strategies, didactics, among others, prevent in some cases the proper development of the teaching-learning processes. These circumstances entail carrying out a study in which the educational community can carry out a process of self-reflection on the commitments that each one has. In short, the training processes must be analyzed both by the teaching body, as well as by parents and students.

In this work, the general objective was to know the perception of the educational community about the influence of affectivity on the academic performance of the students of the I.E. El Resbalón of the municipality of San José del Guaviare. Therefore, affectivity and academic performance were taken as axes of analysis and a discourse analysis was carried out, in order to propose a grounded theory that would allow establishing the relationship between the aforementioned axes.

Table 1. Characteristics of groups of adolescent learners.
It should be added that this research is carried out for the benefit of the entire educational community, because when analyzing the role of affectivity in academic performance, it is possible to reflect on conflictive situations and the emotional ties between the members of said community.

\section{Methodology}

In this qualitative research, a phenomenological design with an exploratory and descriptive scope was applied; Thanks to instruments such as document registration, observation, semistructured interview, life history and case study, the information necessary to carry out the discourse analysis was obtained. At this stage of the process, the Atlas.ti software was implemented to analyze the information collected and obtain categories, subcategories and units of analysis.

This data was then triangulated to verify its validity and reliability. The information was obtained with the help of the educational community of the I.E. El Resbalón, from which a sample of maximum variation was taken, consisting of 45 participants: 25 adolescent students, 15 parents and 5 teachers; The students who participated were subdivided into four groups, as shown in Table 1.

Likewise, the qualitative study was carried out from the three stages described below:

- First stage. The perception of students and parents: a diagnosis was made, and documents and records were reviewed to inquire about the academic performance and behavior of the students. Observation was then applied to adolescent students during classes and school break, to obtain information on their behavior and attitudes. Finally, the semi-structured interview was implemented with these students and parents.

With the information obtained, four students were selected by characterizing them by their academic performance and behavior (see Table 1). Each one wrote their life story, there they chronologically described their experiences as children, students and classmates.

- Second stage. The perception of the teachers: the semi-structured interview was applied to the teachers of the I.E. El Resbalón who guide the classes of the participating students. The classes of the teachers of Social Sciences, Biology, Language, Productive Projects and Mathematics were also observed. This exercise was intended to know the pedagogical strategies used by teachers in the teachinglearning processes, and to describe the affective relationships with their students, both in the classroom and outside of it. Also, the

\begin{tabular}{|c|c|c|c|c|}
\hline Groups & Group 1 & Group 2 & Group 3 & Group 4 \\
\hline Characteristics & $\begin{array}{l}\text { Students with high academic } \\
\text { performance and good behavior. }\end{array}$ & $\begin{array}{l}\text { Students with high academic } \\
\text { performance and bad behavior. }\end{array}$ & $\begin{array}{l}\text { Students with poor academic } \\
\text { performance and good behavior. }\end{array}$ & $\begin{array}{l}\text { Students with poor academic } \\
\text { performance and bad } \\
\text { behavior. }\end{array}$ \\
\hline
\end{tabular}


objective was to identify how the relationships between teachers and parents worked.

- Third stage. Affectivity and academic performance: in this last stage, it was determined if affectivity influenced academic performance, through the case study of four adolescent students, and according to the criteria shown in Table 2.

\section{Results}

\subsection{Recurring admonitions towards the adolescent learner}

Upon reviewing the documents and records, annotations were found about the misbehavior of the students. The written reprimands were made for circumstances such as sabotage of classes, the fact of verbally or physically mistreating their classmates, the misuse of cell phones and non-compliance with academic activities. Minutes signed by students and parents were also found, where the former promised to improve their behavior and the latter to verify if they comply with the commitments acquired. It is pertinent to point out that the sanctioning process carried out by teachers to students is repetitive, so that it generates discontent in the latter and decreases their willingness to face the classes. In addition, no other pedagogical measures have been taken to resolve conflicts and / or differences, such as peer chat. In this sense, students describe the reasons for their behavior, and they show expressions of sadness, anxiety, anger, hostility, aggressiveness, guilt, lack of interest in studying, among others.

\subsection{The academic performance of adolescent students from the I.E. El Resbalón}

The academic performance of the eighth and ninth grade students was obtained thanks to the general consolidation of the evaluations carried out by the teachers of the different subjects. In the general grade sheets the low academic performance is notorious, since it is observed that they fail from one to seven subjects. It should be clarified that this performance is measured through the formative evaluation process: based on the observation, the teacher makes reflections on the performance of the students, describes and qualifies the weaknesses, strengths and achievements, among other aspects that may influence in the teaching-learning process of the adolescent student.

According to MEN (2010), student learning should be assessed taking into account a final product, either through written or oral tests, pedagogical or productive projects, drawings, inquiries in the community, theatrical performances, role-plays or songs. In the IE El Resbalón, teachers use different instruments to measure the academic performance of students, some of them are exhibitions, research projects, participation in classes, cooperative workshops, written or oral tests, elaboration and socialization of diagrams, concept maps and metals, among others.

The evaluation system of the I.E. El Resbalón has a rating scale from 1.0 to 5.0 ), where it is failed with a rating between 1.0 to 2.9 , and is approved with a minimum grade of 3.0 to a maximum of 5.0. In the evaluations it is observed that Mathematics, for example, was approved only by $29 \%$ of the students; Language was only approved by $18 \%$; Natural Sciences $74 \%$ of the students approved it; Social Sciences 54\% and Pedagogical Projects $86 \%$ of adolescent students. Finally, only $7 \%$ of the students passed all the subjects.

\subsection{Attitudes of teachers and adolescents during the development of classes}

During the sessions, the teachers interrupted their classes repeatedly to attract the attention of the students, who were distracted by talking or using their mobile phones. To attend to the distraction, the teacher addressed the group and expressed the rules regarding cell phone use.

In general terms, during the different sessions there was no evidence of affective rapprochement between teachers and students, on the contrary, some teachers showed expressions of anger or disgust at the attitude of the students, who promoted indiscipline in the classroom. However, there was no evidence of verbal, physical or psychological abuse towards adolescents.

On the other hand, it was observed that the classes are not dynamic, in these the instruments stipulated in the principles of the new-active school methodology are not worked. Neither are group activities considered, with which students would be motivated to start the school day or sessions. This type of activities would favor affective relationships between teachers and students.

Table 2. Sociodemographic characteristics of adolescent learners.

\begin{tabular}{|c|c|c|c|c|c|c|c|c|c|}
\hline $\begin{array}{c}\text { Teenagers } \\
\text { (pseudonym) }\end{array}$ & Age & Grade & Group & $\begin{array}{c}\text { Type of } \\
\text { home }\end{array}$ & $\begin{array}{c}\text { Time of arrival } \\
\text { at home }\end{array}$ & $\begin{array}{c}\text { Father's } \\
\text { occupation }\end{array}$ & $\begin{array}{c}\text { Mother's } \\
\text { occupation }\end{array}$ & Lives with & $\begin{array}{l}\text { father-mother's } \\
\text { schooling }\end{array}$ \\
\hline Antonia & 14 & Nineth & 1 & Own & 4:20 p. m. & $\begin{array}{c}\text { Electric } \\
\text { technician }\end{array}$ & Housewife & $\begin{array}{l}\text { Mom and } \\
\text { brothers }\end{array}$ & $\begin{array}{l}\text { Eleventh and } \\
\text { tenth }\end{array}$ \\
\hline Viviana & 15 & Nineth & 2 & Alien & 3:50 p. m. & Farmer & Housewife & Mom and Dad & $\begin{array}{l}\text { Eleventh and } \\
\text { fourth }\end{array}$ \\
\hline Miguel & 15 & Eighth & 3 & Alien & $3: 20$ p. m. & Farmer & Independent & Father & $\begin{array}{l}\text { Fifth and } \\
\text { eleventh }\end{array}$ \\
\hline Siro & 16 & Nineth & 4 & Alien & 4:30 p. m. & Farmer & Farmer & $\begin{array}{c}\text { Dad, mom and } \\
\text { brothers. }\end{array}$ & $\begin{array}{c}\text { Fourth and } \\
\text { Second }\end{array}$ \\
\hline
\end{tabular}

Source: Own elaboration based on the information obtained from questionnaires and student history. 


\subsection{Attitudes of adolescents during school breaks (rest)}

During breaks, students address different topics of conversation, such as music, reggaeton singers, movies, soap operas, family matters, personal problems, classmates, teachers, among others. Adolescents consider that parents argue frequently, they do not trust their children and are jealous in matters of friendship or dating, especially in the case of girls. At the same time, it was observed that they have conflicts with friends, particularly because of jealousy, when they establish friendly relationships with other colleagues. They are always on the lookout for some attractive boy (a) from school or from the sidewalk, to establish friendship or dating relationships; the latter usually occur in secret from the parents. In general, adolescent students yearn for spaces, during each session, to carry out activities such as talking about topics different from those proposed in the subjects, playing micro-football and / or connecting to the internet through mobile phones, etc. To the above is added his desire that parents and teachers give them the possibility to express their feelings freely, by allowing them to have dating relationships.

Regarding the educator-teacher relationship, it was detected that the students have fun with the teachers of Language and Social Sciences, play "microfootball" and talk; It could be said that these are the spaces for dialogue and trust for the participants, where even the teachers tell anecdotes and make the students laugh.

It is clear that they prefer recreational activities that imply less effort to acquire knowledge, instead of putting more effort into their academic training process. Likewise, despite the fact that the teacher allocates some spaces for fun, adolescents continue to be irresponsible with academic activities.

\subsection{Perception of adolescent learners}

Adolescents have physical and biological changes in their life stage, so in some cases they are victims of bullying. The school is a space where the student, on occasions, enforces her rights, to avoid being the object of ridicule, sabotage or bullying. However, conflicts between adolescents cause the affective relationships between them to deteriorate, which generates discrimination towards those conflictive partners.

For example, in the teaching-learning processes the discrimination of peers is evidenced because they have different learning rhythms; This causes demotivation, sadness and/or depression and, at the same time, fosters a bad coexistence in rejected adolescent students; these circumstances often generate cases of school dropout.

In these cases, teachers are closer to adolescents who have good behavior during classes, and whose performance is remarkable. These students come from family nuclei with a healthy coexistence, in general terms, so that they solve conflicts easily. On the other hand, there are other families that resort to verbal, physical and psychological abuse, which can lead to poor academic performance and misbehavior of students in the teaching-learning processes.

Faced with this, the adolescent students of the I.E. El Resbalón considered that family problems arise due to the absence of affection on the part of the parents, and that this fact notably affects their academic performance. It should be noted that students who have been successful in academic performance receive emotional and / or affective support from their parents, from childhood. Parents' perception

According to the parents, adolescents want to make decisions without receiving their guidance, and they almost do not comply with the rules that are had at home, on the contrary, they deny their school and family duties. Regarding academic performance, parents are aware of the school success or failure of the adolescents of the I.E. El Resbalón. When addressing the issue, they recognized the commitment of their children in academic activities, or the lack of responsibility before them. In addition, it was identified that those who are parents of adolescents with high academic performance manifest expressions of affection towards their children, since they conceive that these are key to the training process, to the extent that they make them feel motivated.

In summary, the parents of the I.E. El Resbalón have the perception that affectivity - specifically, the expression of affection - is crucial for students to obtain high academic performance and feel support in their training process.

\subsection{Perception of teachers}

Teachers' perception of coexistence among adolescents is congruent with that expressed by parents and students, to that extent, a healthy coexistence between them is perceived, evidenced in their expressions of affectivity. However, there have been some episodes of aggression among adolescents that have required written reprimands.

According to the perception of teachers, adolescents show laziness when they have to fulfill their academic activities, and are distracted in the teaching-learning processes. Their affective approach towards students is minimal, mainly in the case of those who have bad behavior, which leads to ignorance of the causes of negative attitudes in the training process. The teacher-educating approach is only academic.

Affective treatment, from the teachers' perspective, is essential in these processes, not only at school, but also at home. There have been cases of students who are discriminated against by their peers, because they do not behave in the appropriate way and their academic performance is low; Most of the time it is complex for these learners to maintain a healthy coexistence with their peers, and it is possible that their attitudes are due to the conflicts they face within the home. It is pertinent to clarify that adolescent misbehavior is not a reason for teachers and parents to avoid affective relationships with them, on the contrary, it is best to strengthen them to establish an affection approach that allows them to identify the reasons for their attitudes, in order to guide or advise them.

\subsection{The influence of affectivity on academic performance}

On the other hand, it has been observed that teachers have more affective closeness with students who are in the vital stage of childhood, pampering them, hugging them and giving them expressions of love and affection. Thus, students feel more loved by teachers when they are in this stage, and despite their bad behavior in the teaching-learning processes. An example of their attitude towards older students was found in the perception of these students, 
who noticed when teachers felt empathy or not for them, since they expressed that some advised them, but others did not want to have them in the classroom. lessons.

As for parents, some of the adolescents who currently have a high academic performance have obtained these results since childhood, and they considered that their parents have always supported and guided them. In contrast, the case of a student who has difficulties with his academic performance from elementary school was observed; Although his parents were aware of his academic activities, he stated that he has always had difficulties writing.

In any case, if adolescents do not have this closeness with their parents and the necessary support, they are at risk of experiencing negative behavioral changes, both at home and at school. The partial abandonment of parents encourages behaviors that affect academic performance.

As a last point, it should be considered that the adolescent usually has friends with whom he wishes to spend most of his time; everyone likes to have fun with their friends more than with anyone else, in addition, some parents almost never have time to share with their children, as they arrive tired from work. Because of this, friends are the ones who advise, support and support them, keep secrets from them, become their accomplices. Unfortunately, there are also "friends" who are bad advisers and induce them to lack of discipline, to drink alcoholic beverages, to consume drugs, among other activities that are not very beneficial for them.

\section{Discussions}

Concordance was found in the study with what Medrano et al. (2015) on the emotions of positive affect and negative affect of students, who experience joy, interest, sadness, fear and anger, according to the circumstances that arise in their contexts. It is possible to say that the adolescents of the I.E. The Slip frequently reflect these emotions, and it was observed that those of a negative nature stand out, such as sadness, fear and anger, in particular, in those who show low academic performance.

In relation to this, authors such as Barrera et al. (2006) expressed that, if the family context becomes a set of aggressive expressions, boys and girls will find a source of imitation of aggressive behaviors. Surely, the aggressions that students commit against their peers and the bad behavior during the classes can be due to the conflict situations that they experience daily at home.

Psychosocial factors that affect academic performance, even more so in adolescents, usually arise when the student begins to experience changes associated with biological, intellectual, emotional and social aspects, typical of that stage (Güemes, Ceñal \& Hidalgo, 2017). In this case, through the discourse of the teachers and parents, these transformations were identified in them, which generate unstable behavior that causes conflicts at home and at school.

This assertion is supported in the study by Silva and Mejía (2015), who found that in the period of adolescence there is a cluster of disordered emotions that intervene in various circumstances. Adolescents seek belonging, empathy, fun and identity, at the same time, they have the need to excel and isolate themselves from adults, but are sometimes inhibited by parents and teachers. There are parents of EI El Resbalón who are not prepared to face these emotions of their adolescent sons and daughters, so they try to correct them through verbal and physical abuse, and not through affective approach and dialogue, with what that would give them the confidence to express their feelings.

In accordance with the qualitative study carried out by Narváez (2017) in Colombia on the affective traits of students' learning styles, affective attributes are key to the socio-cognitive disposition towards learning objectives and tasks. In this regard, the educational community emphasized that the cognitive process must be supported from the affectivity, so that the learner is constantly motivated by the people around him. Adults should also show trust, empathy, tolerance and understanding towards them, and talk about how they approached those moments when they were young.

Now, in the new educational trends, affectivity must be implemented as a pedagogical reality, where teachers and parents take into account the emotions, style and pace of learning of students; in this way, it will be possible to create friendly and affectionate environments that promote good academic performance. According to Berger et al. (2014), the association between the socio-emotional dimension and the academic performance necessary to achieve success in these processes has been evidenced. In this sense, rather than giving orders for the student to carry out their academic activities, the teacher must formalize an affective and motivating communication, being aware that affective relationships facilitate communication and make a good educational process possible.

Because school is the basis for the application of values, since it is the first stage of social interaction of the student, it is up to this to direct the teaching of affectivity. For Páez (2017), in the school environment, sometimes children and adolescents do not have human relationships that help them interact with others. In his study, it is perceived that on some occasions teachers put aside their human sense, which is why incomprehension appears when faced with unfavorable situations for students, to the point where they judge them without knowing the socioeconomic and/or psychosocial conditions they live in their homes. Regarding the concept of affectivity, when considering expressions of affection, according to the adolescent's speech, there are cases in which they feel an emptiness or absenteeism from the parents. Consequently, some find in school a means to vent and get rid of their problems, through fights with classmates or teachers. Little by little the adolescents become demotivated, which confirms the argument of Godoy and Campoverde (2016), who assured that they drop out of school when they find calls for attention and constant written reprimands from the teachers, instead of motivation and support.

From the point of view of the students, parents and teachers of the I.E. El Resbalón, affectivity does influence academic performance, so that relationships and expressions of affectivity towards children favor this process. In practice, there were cases of adolescent students who feel alone and without support, and who have not received expressions of affection from their parents; It is precisely they who obtain poor academic performance and maintain bad behavior that causes problems of coexistence in the classroom. 
Likewise, the students considered that there are angry teachers who give them frequent reprimands and do not inspire confidence to ask questions in class, while there are others who are more friendly and whose classes are interesting. Others expressed that there are teachers who are very dedicated to their work and responsible for class programming, but that in some cases they become strict and rigid with academic activities. It could be said that these teachers are the ones who do not establish any affective bond with the students, and rarely talk with them. However, the teachers stated that they try not to be so close to the students because they fear that they will abuse their trust and disrespect them.

In summary, when analyzing the similarities and differences of the participants' perceptions about the influence of affectivity on academic performance, it was found that in order to achieve high academic performance, adolescents must have constant and affective communication with parents and teachers. Thus, teachers must implement an affective or emotional education that creates an affective bond with the students, with the aim of generating trust and pleasure towards the classes. Friendly and pleasant environments in the classroom are also necessary, so that adolescent students do not feel apathy for the class or for the teacher; According to Zumaeta, Fuster and Ocaña (2018), if the teacher expresses positive affectivity, good personal relationships are created with the students, and with it a high academic performance.

\section{Conclusions, remarks and recommendations}

With this study it is concluded that the academic performance of the adolescent student is negatively affected by the lack of affective relationships with the parents, who do not dedicate enough time -as they did in childhood - to listen to them and understand their emotions and feelings. In turn, the low academic performance of adolescents is due to permanent conflicts within the home, where verbal, physical and psychological aggression occurs by the father of the family.

Another important factor is constituted by the interests of adolescent students, since they do not usually contemplate academic performance, instead, they focus on dating relationships, music, sports, fashion, social networks, groups of friends, among others. In addition to this, during this stage they show certain differences with their parents, especially in terms of the advice they give them on compliance with rules and the application of values and moral principles. It is a fact that some adolescents feel alone at home and do not receive parental or maternal affection.

On the other hand, adolescent students would like some teachers to improve their attitude during classes, ideally, they would be more friendly with them, to have greater confidence and thus improve their academic performance. As is well known, in the teachinglearning process, teachers must develop emotional competencies that favor this process, so that a teacher-educator approach is generated and there is a motivation that contributes to increasing the interest of the latter in their academic training, social and personal. Currently, the MEN performs an annual performance evaluation of the teachers appointed by Decree Law 1278 of 2002, in order to assess the creativity and commitment with which teachers and teacher managers carry out their work. An evaluation protocol is then implemented with which emotional competencies are valued, which is pertinent to potentiate those affective relationships so necessary in the teaching-learning processes, for the benefit of the students.

It should be remembered that the adolescent who does not receive expressions of affection and is mistreated by the father of the family, is also reprimanded by the teachers; In response to this, the student shows no interest in his training process, and becomes an aggressor and undisciplined. Due to poor academic performance and calls for attention, the student may even drop out of school, and will feel rejected and misunderstood by other people.

One of the strengths of this research is the validity and reliability of the information obtained, since the collection instruments allowed obtaining real and verified data through triangulation. There were coincidences in the answers given by the students, parents and teachers, and the veracity in the provision of the information was confirmed, since the issues addressed were observed through the interview and the life history of the adolescents. Meanwhile, the participants' discourse was clear and concise, as they described the events as they are, so that it was possible to recognize the problem and understand that a reflection was needed to mitigate it. To Face this phenomenon, parents stated that they were willing to receive guidance from the parents' school to develop competencies in affective relationships with their sons and daughters. The teachers, thanks to their professional ethics, recognized that it is necessary to implement affective relationships with students so that they have confidence and empathy towards the classes. Fortunately, the limitations that arose in the research were minimal, because the data collection instruments were properly implemented, and the way in which the participants were approached to obtain accurate information was appropriate.

It should be added that El Resbalón does not have a curriculum and/or study plan that guarantees the academic inclusion of students with learning disabilities, as analyzed in this work. Hence, it is necessary to reiterate the case of the adolescent student who has repeated two courses; Although he has dyslexia and dysgraphia, the teachers do not develop special activities for him and his learning rhythm is not respected. With this example it is evident that this institution does not have teachers with experience in the management of those students with cognitive disabilities.

As in the I.E. El Resbalón, other educational institutions can present this type of problems that imply the absence of expressions of affection towards adolescents and difficulties in their academic performance. It was evidenced that students are not understood or oriented towards making adequate decisions, and they feel accused, pointed out or reviewed, which leads to negative attitudes, low selfesteem, low academic performance, school dropout, links to violent groups, among other conflict.

For the reasons stated, this qualitative study, applied at the local level, can be of great relevance at the departmental and national level, insofar as it reveals the importance of affectivity in the student's academic performance, and therefore could lead to reflections on the matter, from the educational work and the functionality of the family. 
Based on the discussion and the conclusions raised, the following recommendations emerge:

- The teaching body should promote frequent meetings with parents to monitor the academic, social and personal teachinglearning processes of students, and in order to provide guidance on the nature of a vital stage such as adolescence.

- It is essential that the educational director of the institution take the initiative to carry out permanent training workshops for teachers, in which the foundation and principles of constructivism are emphasized, mainly with regard to the development of emotional competencies.

- The I.E. The Slip should propose the development of a special curriculum for students with special educational needs, which includes study plans and class plans that guarantee their cognitive development.

- Teachers must maintain continuous contact with parents, particularly those who have abused their children, in order to guide them or give them recommendations that redirect the affective relationships between household members.

- In an institutional pedagogical program or project, with the support of parents, it is pertinent to carry out workshops and / or motivational talks for adolescents, in such a way that they can reestablish affective relationships in the family nucleus.

- In the classroom it is necessary to address content to obtain knowledge, and at the same time, cover it from an emotional approach, so that the student and the teacher can interact and strengthen their affective bond.

- In the future, studies can be carried out on the characterization of students, with a view to identifying those who have difficulties in the learning processes, and thus develop curricular meshes and / or inclusive study plans, to guarantee them a quality education. The characterization and the parents' school can go hand in hand with an analysis of how the implementation of the new-active school methodology occurs in rural educational institutions of the department of Guaviare.

斗

Conflict interest. Author declare that there is no conflict of interest regarding the publication of this paper.

Acknowledgements. Jaime Beltran Bernal thanks to Mindtech s.a.s. (AFICAT MT-UV 2018-2023) for publication funds.

\section{References}

Barrera, D., Restrepo, C., Labrador, C., Niño, G., Diaz, D., Restrepo, D., y otros. (2006). Medio familiar y entorno escolar: detonantes y antídotos de las conductas agresivas en niños en edad escolar. Persona y Bioética, 10 (2), 99-107.

Calupiña, R., \& Zambrano, K. (2018). El desarrollo socio-afectivo de la educación y el rendimiento académico. Obtenido de Universidad Técnica de Cotopaxi: http://repositorio.utc.edu.ec/bitstream/27000/4446/1/PI-000600.pdf

Godoy, M., \& Campoverde, B. (2016). Análisis comparativo sobre la afectividad como motivadora del proceso enseñanza-aprendizaje Casos: Argentina, Colombia y Ecuador. Sophia, 12 (2), 217-231.

Güemes, M., Ceñal, M., \& Hidalgo, M. (2017). Pubertad y adolescencia. Revista de Formación Continuada de la Sociedad Española de Medicina de la Adolescencia, 5(1), 7-22.

Narváez, J. (2017). Rasgos afectivos de los estilos de aprendizaje de los estudiantes de la Facultad de Educación de la Institución Universitaria Cesmag, Pasto, Colombia. Actualidades Pedagógicas, 71, 129-151.

Páez, R. (2017). Tendencias de investigaciones sobre la familia en Colombia. Una perspectiva educativa. Revista Latinoamericana de Ciencias Sociales, Niñez y Juventud, 15 (2), 823-837.

Palacios, J., Marchesi, A., \& Coll, C. (1999). Desarrollo psicológico y educación. Psicología Evolutiva. Madrid: Alianza Editorial.

Rodríguez, G., Amuchástegui, A., Rivas, M., \& Bronfman, M. (1995). Mitos y dilemas de los jóvenes en tiempos del SIDA, Adolescencia y género. México: Conasida.

Silva, I., \& Mejía, O. (2015). Autoestima, adolescencia y pedagogía. Revista Electrónica Educare, 19(1), 241-256.

Zumaeta, S., Fuster, D., \& Ocaña, Y. (2018). El afecto pedagógico en la didáctica de la matemática - Región Amazonas desde la mirada fenomenológica. Propósitos y Representaciones, 6(1), 409-462.

斗

(C) MT-Pallantia Publisher (2020) 